\title{
Tax Planning in Fundraising Activities
}

\author{
Zhang Peilu
}

\begin{abstract}
The paper describes the tax planning in fundraising activities. The normal operation of each enterprise cannot be separated from the funds; financing activities are an important part of the next series of economic activities. Financing not only needs to raise enough funds, but also to minimize the cost of capital. In the different financing plan, the amount of the tax is different, tax factors affect the merits of the scheme, and financing costs will affect the cost of production and operation of enterprises, which will affect the competitive power of enterprises. Therefore, when enterprises are raising money, if we can adopt the best financing plan with financing skills, you can minimize tax and save benefits, which will provide a reliable guarantee for the production of capital management strategy of the enterprise and improve the implementation of the sustainable competitiveness of enterprises. Therefore, this article discusses the tax issue in the selection of financing options in enterprises. The thesis uses comparative analysis method and case analysis method. In the process of financing, enterprises should keep in mind the business management objectives of maximizing corporate value, determine the ratio of debt capital to equity capital, and select the appropriate financing method according to the characteristics of the enterprise.
\end{abstract}

Index Terms-After-tax profits, financial management, financing decisions, tax, tax planning.

\section{INTRODUCTION}

Due to the rapid economic development in recent years in China and the unpredictable operating environment, various industries are facing different degrees of challenges. Whether the next series of development projects and operating activities of the enterprise can be carried out smoothly is determined by the financing behavior of an enterprise. The movement, circulation and turnover of the enterprise funds are important indicators of the performance of the financial management. Therefore, raising funds is an important part of the company's daily financial activities. A large part of the company's cash outflow includes tax expenditures. Tax planning is a prerequisite for financial managers to make reasonable and effective financial decisions. Therefore, the selection of financing options should focus on taxation.

\section{The NECESSITY OF TAX PLANNING IN FINANCING ACTIVITIES}

\section{A. It Can Minimize the Cost of Raising Capital and Maximize the Profit}

The cost of raising capital is part of the cost of the enterprise, in order to increase the profit, it is possible for

Manuscript received July 16, 2018; revised March 1, 2019.

The author is with Shandong Jiaotong University, China (e-mail: 361194132@qq.com.). enterprise to reduce the cost of raising capital. On the premise of following the rules and regulations of the enterprise, the enterprise may make full use of the preferential policies in the tax regulations to reduce the cost of financing and achieve the goal of increasing the profits of the enterprise.

\section{B. It Provides a Prerequisite for a Company to Make Sound Financial Decisions}

In the process of raising funds, enterprises will be affected by the demand for and supply of capital, market interest rates, inflation and deflation, and the renewal of tax policies, which increases the difficulty of raising money for businesses [1]. If a company wants to raise money, and it has two methods, bond issue and stock issue. Bond interest rate is $7.9 \%$, common stock financing costs around $7.3 \%$. If it doesn't consider the tax, the enterprise should choose bond issue to raise money, but when all factors are taken into account, it turns out that bond interest can be deducted before interest, so the cost of raising money for bond issuance may be lower.

\section{It Can Promote the Establishment of a Modern Enterprise System}

With the gradual establishment and improvement of the market economy system, enterprises can raise funds in various ways and provide strong financial support to their development. In this process, enterprises gradually realize the effect of scientific financing management, which is invisibly beneficial to the establishment and improvement of modern enterprise system.

\section{The PrinCIPLES OF TAX PlanNING IN FUnd-RAISING ACTIVITIES}

In the selection of a company's financing plan, reasonable tax planning can reduce the tax cost, so most companies will plan for taxation. Tax planning must grasp the following principles in financing activities.

\section{A. Legality}

Firstly, the tax planning of enterprises in fund-raising activities must comply with all relevant national laws and regulations. Tax planning can only be carried out within the scope allowed by the tax law. It must not evade the tax burden and violate the tax laws and regulations. The national laws and regulations may change at any time, so the enterprise planning scheme needs to change at any time. The senior financial management of the enterprise needs to pay close attention to the change of laws and regulations, so as to make legal planning.

\section{B. Serving Financial Decisions}

Fundraising activities are part of financial activities. Tax considerations in fundraising schemes can affect the 
distribution of profits, investments, and other financial decisions. Therefore, tax planning needs to closely link with corporate financial decisions, based on the overall interests of the company, and make correct scientific and feasible financial decisions to determine whether the financing plan can bring absolute benefits to the company.

\section{Maximize Financial Benefits}

The ultimate goal of tax planning in financing schemes is to maximize the value of the company. In tax planning, we should not only consider the tax issue, but also consider the influence of management cost, financial cost, production cost and other factors. We should see not only the short term, but also the long term; Increase capital as well as income. Consider not only the present financial benefits, but also the future benefits [2].

\section{CORPORATE FINANCING OPTIONS AND TAX PlANNING}

\section{A. Tax Planning in Debt Financing}

Debt-oriented financing is a method of financing in which an enterprise obtains a sum of money at the agreed cost and for the purpose for which it is required to repay its debts. Debt-oriented financing mainly includes short-term borrowing, long-term borrowing, issuing bonds, and borrowing from the enterprise's internal workers or the public. For enterprises, debt financing is pre-tax interest payment, which has a certain anti-tax effect, its main cost is the interest paid to financial institutions (such as banks), and after interest is returned, the profits will be reduced, so that the tax burden will be reduced, because the expenses and interest generated in the financing can be included in the pre-tax cost which can deduct income tax. For example, a company has obtained a long-term loan of 1 million Yuan for 5 years, the financing expense ratio is $0.5 \%$, and the annual interest rate is $10 \%$, so the enterprise can pay less income tax of $13[(100 \times 5 \times$ $10 \%+100 \times 0.5 \%) \times 25 \%$ ) million.

In general, interest on debt financing and fund-raising expenses can be included in the pre-tax costs and expenses before deduction of income tax, and achieve tax credit. Assume that without considering the risk factors and the constraints of risk costs, if the company operates in debt, and the interest on debt will not change. When the profit increases, the interest paid by each unit of profit will be relatively reduced, which can increase the income of investors. But this analysis does not take into account the cost of risk. As the cost level of debt rises above the EBIT, equity capital yields will decline. Therefore, the tax planning of companies through debt financing requires that the EBIT is higher than the debt cost rate.

\section{1) Lending investment}

In order to facilitate fundraising, borrowing business is often generated between enterprises. If it is a group company, it can also establish a financial center to realize the internal fund lending business. In this way, the Group can carry out fundraising activities based on its own resources and reputation, and undertake financial risks. It can also adjust the debt ratio and capital structure. In addition, the financial center also ensures the group's fund management effect and tax benefits: using internal lending, tax transfer between enterprises with different tax rates; using interest income planning to achieve the effect of delaying tax payment or tax credit [3].

\section{2) Bond investment}

The bond amortization method includes two methods: the straight-line method and the actual interest rate method. Although different amortization methods will not affect the sum of interest expenses, they will have an impact on the amortization of interest expenses. For the straight-line method, the bond premium is mainly distributed to each year, and the interest expense for the current year is offset. For the effective interest rate method, the product of the present value of the bond and the actual interest rate is compared with the interest paid, and the difference is treated as a premium amortization. It is characterized by a downward trend in interest expenses and a premium. The amortization amount is increasing Therefore, when issuing bonds through a premium, the actual interest rate method should be chosen because the premium amortization in the pre-stage of the enterprise is less than the straight-line method, and the interest expense is larger than the straight-line method. The income tax in the previous period is relatively small, and the income tax in the later period is relatively small. Many. Therefore, due to the consideration of the time value of money, the actual interest rate method is used for amortization in the process of tax planning, and deferred taxation can be carried out.

\section{3) Bank borrowing funds}

Bank loans mainly include ordinary loans and state policy loans. These two types of loans will not only bring financial leverage benefits to enterprises, but according to the relevant requirements in the tax law, if the loans are implemented to financial institutions, the interest expenses of the enterprises need to be deducted according to the actual amount, that is, the loan interest rate of the enterprises. Reduced. For example, the borrowing rate is $6 \%$.And the income tax rate is $25 \%$, then the actual interest rate assumed by the enterprise is only $4.5 \%$. As long as the enterprise's return on investment is higher than $4.5 \%$, the financial leverage can be fully utilized, thereby increasing its own tax revenue [4].

\section{B. Tax Planning in Equity Financing}

\section{1) Issuing shares}

Issuing stocks is an important way for the company to raise funds. Enterprises need to pay dividends after issuing shares. Whether it is common stock or preferred stock, according to the provisions of the tax law, dividends are deducted from after-tax profits, so there is no tax incentive to issue stocks, which results in an increase in tax costs. Therefore, the single fundraising method of issuing stocks is not the best fundraising plan. The key of equity financing determines the ratio of debt capital to equity capital in capital structure [5]. For example, when the investment profit rate is higher than the interest rate, expanding the scale of the debt appropriately can increase the equity capital return rate of the company. However, if the debt ratio is too high, the proportion of debt 
capital and equity capital is too large, the lower the return rate of its equity capital will be, and the repayment pressure will be too great, and even a loss will lead to bankruptcy.

The following example is to study tax considerations in financing scheme selection under the combination of corporate debt financing and equity financing.

For example, A Co., Ltd. is expected to raise 1 million yuan for the R\&D and production of new products, and the forecast annual profit before interest and tax is 300,000 yuan.

There are three options available:

Option One: Equity financing of 1 million yuan, additional ordinary shares 200,000 shares, 2 yuan per share, debt capital: equity capital $=0: 100$;

Option 2: Adopt a combination of equity financing and debt financing, in which the bank borrows 300,000 yuan, the debt interest rate is $10 \%$, and additional common stock is 350,000 shares, 2 yuan per share. Debt capital: equity capital $=30: 70$;

Option 3: Adopt a combination of equity financing and debt financing but adjust the proportion, including borrowing RMB 500,000 from the bank, and the interest rate of the liability is $10 \%$, issuing additional common shares of 250,000 shares, 2 per share, debt capital: equity capital $=50: 50$.

The corporate income tax rate is $25 \%$.

\begin{tabular}{|c|c|c|c|}
\hline Project Plan & Option 1 & Option 2 & Option 3 \\
\hline $\begin{array}{l}\text { Capital } \\
\text { Structure } \\
\text { (Debt Capital: } \\
\text { Equity } \\
\text { Capital) }\end{array}$ & $0: 100$ & $30: 70$ & $50: 50$ \\
\hline EBIT & 300,000 & 300,000 & 300,000 \\
\hline $\begin{array}{l}\text { Liabilities } \\
\text { Profit }\end{array}$ & 0 & $10 \%$ & $10 \%$ \\
\hline $\begin{array}{l}\text { Liabilities } \\
\text { interest }\end{array}$ & 0 & $\begin{array}{l}300,000 * 10 \% \\
=30,000\end{array}$ & $\begin{array}{l}500,000 * 10 \% \\
=50,000\end{array}$ \\
\hline $\begin{array}{l}\text { Profit before } \\
\text { tax }\end{array}$ & 300,000 & $\begin{array}{l}300,000-30,000=2 \\
7,000\end{array}$ & $\begin{array}{l}300,000-50,000 \\
=25,000\end{array}$ \\
\hline $\begin{array}{l}\text { Corporate } \\
\text { income tax } \\
\text { (tax rate is } \\
25 \% \text { ) }\end{array}$ & $\begin{array}{l}300,000 * 25 \\
\% \\
=75000\end{array}$ & $\begin{array}{l}27,000 * 25 \% \\
=67500\end{array}$ & $\begin{array}{l}25,000 * 25 \% \\
=62500\end{array}$ \\
\hline Profit after tax & 225000 & 202500 & 187500 \\
\hline $\begin{array}{l}\text { Pre-tax return } \\
\text { on equity } \\
\text { capital }\end{array}$ & $\begin{array}{l}300,000 / 1,0 \\
00,000=30 \\
\%\end{array}$ & $\begin{array}{l}270,000 / 700,000= \\
38.6 \%\end{array}$ & $\begin{array}{l}250,000 / 500,00 \\
0=50 \%\end{array}$ \\
\hline $\begin{array}{l}\text { After-tax } \\
\text { return on } \\
\text { equity capital }\end{array}$ & $\begin{array}{l}225000 / 100 \\
0000=22.5 \\
5 \%\end{array}$ & $\begin{array}{l}202500 / 700000=2 \\
8.9 \%\end{array}$ & $\begin{array}{l}187500 / 500000 \\
=37.5 \%\end{array}$ \\
\hline
\end{tabular}

Through the analysis of the above three options, the proportion of debt financing raised from 0 to $30 \%$ and increased to $50 \%$, while the corporate income tax should be reduced from 75,000 yuan to 67,500 yuan and then reduced to 62,500 yuan, after tax Equity capital yield increased from $22.55 \%$ to $28.9 \%$ and then rose to $37.5 \%$, so scheme 3 is the best. However, it is not favorable for the enterprise to increase the proportion of unrestricted debt financing under all conditions. Attention should be paid to financial risks.

\section{2) Self-accumulation}

Self-accumulation is the fund raised by the enterprise using its own capital and accumulated in the process of production and operation. Retained earnings are after-tax profits and cannot be tax-deductible. There is no tax saving effect for this type of financing. The reinvestment of profits obtained over the years represents that the owner and user of the funds are the same subject, that is, if after-tax profits still $r$ reinvest, it will be taxed, and it is difficult to apportion and offset taxes, so double taxation arises [6].

\section{3) Retained earnings}

Retained earnings refer to the company's internal profits accumulated from previous years or retained by the company. Retained earnings are generated from profits that are realized in the production and business activities of the company. Retained earnings refer to surplus reserves and undistributed profits. Surplus reserves include statutory surplus reserve funds and arbitrary public accumulation funds, which belong to accumulated surpluses for specific purposes [7]. Undistributed profits are part of the owner's equity of enterprises, and are accumulative surpluses without specific purposes. Without considering the opportunity cost of retained earnings, although the cost of funds for retained earnings is low, retained earnings are after-tax earnings, which are retained earnings after the company pays income tax. Therefore, the retained cost cannot be tax deductible, so the method of financing retained earnings does not have a tax-saving effect.

\section{Tax Planning in Lease Financing}

Lease financing refers to a contractual act in which the lessee occupies and uses the lessor's property rights within the agreed period on the condition that the rent is paid. The lease financing methods mainly include operating leases and financing leases.

In the business lease, the lessee can avoid the burden and risk caused by long term equipment, and then reduce the profit from the rental costs in the process of operation in order to reduce the tax burden.

Financing leases are essentially leases that transfer risks associated with ownership of assets. The lessee pays rent to the lessor in installments. During the lease term, the lessee only has the right to use the leased equipment and the ownership belongs to the lessor. The fees and interest in the finance lease fee can be directly deducted from the taxable income in the current period of payment. Leases can achieve the purpose of transferring profits and tax reductions. When the lessor and the lessee belong to the same group, they can directly and publicly transfer the assets of one individual as another individual, and consider the overall benefits to consider charging an appropriate rent. The essence is the internal transfer of profits within the group and the reduction of tax burden [8].

\section{ANALYSIS OF TAX-SAVING EFFECT OF FINANCING CHANCEL COMBINATION}

The ratio of debt capital and equity capital determines the 
structure and composition of the capital structure. Whether the capital structure is reasonable depends on whether the debt ratio is reasonable. The large debt ratio of enterprises shows that the business risk of enterprises is high, but the amount of pre tax deduction is also high, so there is obvious tax saving effect [9]. Therefore, the limitation of the ratio of debt ratios, the choice of financing options and the composition of the capital structure are a reasonable trade-offs between the balance of risks and profits. In the selection of financing options, we should take full account of the operating environment and characteristics of the enterprise and the degree of risk that can be taken in the operation. In practical operation, the feasibility of a single financing scheme is not as feasible as the combination of multiple financing schemes, and the combination of multiple financing schemes can solve multiple financial problems. China's tax law has tax restrictions on different funding methods. A single fundraising method has different levels of taxation, and the effect of taxation is different. Therefore, in order to achieve better tax savings and avoid tax law restrictions, a variety of methods must be adopted. We must use combination of financing channel.

The different fundraising plans make different capital cost of the company and the different income makes the enterprises bear different tax burden. For the overall effect of the enterprise, companies should combine multiple funding methods and adopt multiple portfolio financing schemes. First, the combination of various financing methods is conducive to reducing financial risk and maintaining capital structure. Second, each method of financing has its own advantages and disadvantages. For example, the issuance of bond financing methods has better tax saving effect, but not every enterprise can issue bonds. Even if some companies have the qualifications to issue bonds, the total amount of bonds issued is limited. For example, the company law and securities law stipulate that the total amount of bonds issued by enterprises is less than $40 \%$ of the total net assets of the company. Therefore, in terms of the overall efficiency of the enterprise, there is no one financing method that is absolutely good and definitely bad. The most important thing is to be able to identify a financing combination, choose the optimal financing plan, make full use of taxation policies, and achieve maximum after-tax profits [10].

\section{CONCLUSION}

It is very important for an enterprise to study the tax planning of enterprise financing activities. It can not only judge which is more beneficial to the development of enterprises under different financing activities, but also can reduce the production cost of enterprises. At the same time, it also points out the direction for the future development of enterprises. According to the financing method, the paper mainly gives strategic research on tax planning from the choice of financing structure such as enterprise capital structure selection, bank loan financing, internal and external financing leasing, and combines cases to obtain reliable practical data, and then analyzes tax planning strategies for each financing method.

\section{ACKNOWLEDGMENT}

This paper is based on the research of others. Thanks to these authors. I am grateful to the teachers of the college for their care and guidance in my study life. I am grateful to my colleagues for inspiring the ideas of my thesis. Every time I communicate with them, I will get inspiration and enrich my knowledge. I would also like to especially thank my family for their understanding and support, so that I have the energy to conduct research!

\section{REFERENCES}

[1] C. Bin, "Tax planning in enterprise financing activities," .Finance Communication, pp. 32-34, Dec. 2010.

[2] Q. H. Hou and Q. S. Luo, "Discussion on Fund-raising decision-making in financial management of small and medium-sized enterprises," Business Managerm, pp. 10-11, Aug. 2013.

[3] L. L. Lv and S. F. Wang, "Tax Planning Research in Enterprise Financing Activities - Taking hengfeng paper as an example," Business Eeconomy, pp. 5-6, Sep. 2016.

[4] Y. H. Zou, "Reflections on the tax planning of corporate financial management," Chinese and Foreign Entrepreneurs, pp. 70-71, April 2018 .

[5] W. B. Liu and M. Wu, "Talking about the tax planning in the fund raising of enterprises," Modern Commerce, pp. 34, Nov. 2018.

[6] H. H. Zhang, "Talking about tax planning in enterprise fund raising activities," Cooperative Economy and Technology, pp. 76, Dec. 2013.

[7] D. J. Zhang, Research on Tax Planning in China's Enterprises' Investment and Financing Activities, 1st ed. Chichester, Beijing: China University of Geosciences, 2007, ch. 2, pp. 45-47.

[8] G. Di. Theory and practice of Enterprise Tax Planning, Dalian: Dongbei University of Finance Press, 2012, pp. 212-224.

[9] J. Williams, "Narrow-band analyzer," Ph.D. dissertation, Dept. Elect. Eng., Harvard Univ., Cambridge, MA, 1993.

[10] D. D. Wu, "Research on tax planning of sj corporate financing activities," M.S. thesis, Dept. Tax. Eng., Shen Yang Univ., Shen Yang, China, 2015.

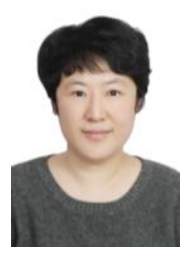

Zhang Peilu was born in Dezhou, Shandong Province, China on December 20, 1981. The major is accounting. She obtained a master's degree from Shandong University of Finance and Economics.

She's teaching at Shandong Jiaotong University since 2007. She has published many articles such as: "Thoughts on China's green tax system under low carbon economy," Friends of Accounting, Sep. 2013; "Discussion on tax planning in e-commerce environment," Financial Communications, Nov. 2011. Her main research direction is financial management. Her main research direction is financial management.

Ms. Zhang was named outstanding instructor of the Sintao Informationization Competition. 